\title{
Elicitor-Induced Defense Response in Soybean Plants Challenged by Bemisia tabaci
}

\author{
Bruna Taiza Locateli ${ }^{1}$, Mycheli Preuss da Cruz ${ }^{1}$, Nean Locatelli Dalacosta ${ }^{2}$, Karine Fuschter Oligine ${ }^{2}$, \\ Edson Bertoldo ${ }^{2}$, Sérgio Miguel Mazaro ${ }^{1}$, Jucelaine Haas ${ }^{1}$, Michele Potrich ${ }^{1} \&$ Caroline Isabella Favetti \\ ${ }^{1}$ Federal Technological University of Paraná, Campus Dois Vizinhos, PR, Brazil \\ ${ }^{2}$ Federal Technological University of Paraná, Campus Pato Branco, PR, Brazil \\ Correspondence: Sergio Miguel Mzaro, Federal Technological University of Paraná, Campus Dois Vizinhos, Km \\ 04, CEP 85660-000, Dois Vizinhos, PR, Brazil. Tel: 55-(46)-3536-8900. E-mail: sergio@utfpr.edu.br
}

Received: August 25, 2018

Accepted: November 1, 2018

Online Published: January 15, 2019

doi:10.5539/jas.v11n2p251

URL: https://doi.org/10.5539/jas.v11n2p251

\begin{abstract}
The whitefly, Bemisia tabaci Biotype B (Hemiptera: Aleyrodidae), is considered one of the world's major agricultural pest groups, attacking a wide range of crop hosts and causing considerable crop loss. Understanding the interactions between whiteflies and host plants promotes the development of novel strategies for controlling whiteflies. This study aimed to evaluate the biochemical alterations caused by induced resistance in soybean plants, challenged by B. tabaci. The experiment was performed at the Federal University of Technology, Parana. Soybean seeds (cv. BRS 284) were sown in polyethylene pots in the greenhouse. The elicitors sprayed on the soybean leaves were: acibenzolar-S-Methyl (ASM-0.005\%); Salicylic Acid (SA-2Mm); foliar phosphite (ULTRA K ${ }^{\circledR}-0.004 \%$ ); Chitosan (CH-1\%); and silicon (SI-0.25\%); whilst the control group was sprayed with distilled water. Plants were infested with 50 adult whiteflies in the cages that were released after applying the treatments. At 0, 24, 48 and 96 hours after the beginning of the experiment, biochemical analyses of total proteins and the activity of the phenylalanine ammonia-lyase (PAL), peroxidases (PO), phenolic compounds, chitinase, and $\beta-1,3$-glucanase were made. The results showed that the application of elicitors increased the route of the phenylpropanoids with the activation of PAL and formation of phenolic compounds. It was also verified the activation of pathogenicity-related enzymes such as peroxidases and chitinase.
\end{abstract}

Keywords: secondary metabolism, resistance to insects, plant defense

\section{Introduction}

Brazil is one of the greatest producers of soybean (Glycine $\max$ (L.) Merrill) in the world. In 2017/2018, Brazil produced 119.28 million metric tons (CONAB, 2018). Nevertheless, insect pests represent a huge challange to soybean productivity and sustainability due to losses and problems related to the abuse of chemical insecticides.

The whitefly Bemisia tabaci (Genn.) Biotype B (Hemiptera: Aleyrodidae) is a polyfagous pest and it is responsible for great losses in production in soybean crops by causing direct and indirect damage (Oliveira et al., 2014; Wang et al., 2015).

Although the whitefly causes little mechanical damage to plants, along with its saliva the insect injects toxins into the phloem; besides, indirect damages are caused by excretion of honeydew, which favours the development of pathogenic fungi, reducing crop productivity (Bôas \& Branco, 2009). This hemipteran is traditionally controlled through insecticides application. There are some limitations though, such as high cost, low efficiency, ecological imbalance and insect resistance (Moraes, Ferreira, \& Costa, 2009). Plant defense induction is a method that can be used alongside other pest control methods in IPM. Its objective is to increase the plant ability to defend itself against biotic stresses such as pathogen and insect attack. These defenses can be activated by treatment with biotic or abiotic agents. These molecules, capable of activating plant defense responses, are called elicitors (Sticher et al., 1997). Among the most studied elicitors, there are acibenzolar-S-methyl (ASM), salicylic acid (SA), phosphites, chitosan and silicon (Cruz et al., 2011; Terra, 2010). The elicitors, when applied to plants, are identified by receptors and then trigger the processes of plant defense (Trouvelot, Héloir, \& Poinssot, 2014).

The induction of resistance against herbivorous can be expressed in two different ways: direct and indirect. Direct induced resistance is mediated by the accumulation of secondary metabolites and defense-related proteins 
(Mithöfer \& Boland, 2012). Indirect induced resistance results in the release of a mixture of volatile organic compounds (VOCs) that specifically attract natural enemies, and are also involved in the mediation of various ecological interactions. Exogenous defense elicitors are biodegradable, used in low quantities and does not lead to pest resistance. Thus, they show potential for the development of new pest control strategies (Mithöfer \& Boland 2012; Pinto et al., 2013).

Research regarding resistance induction of soybean plants against pests are still scarce considering induction potential; thus, this study aimed to evaluate the biochemical changes caused by abiotic resistance elicitors in soybean plants challenged with $B$. tabaci.

\section{Material and Methods}

The experiment was conducted at the Federal University of Technology Parana. Soybean seeds from cultivar BRS 284 were sown in polyethylene pots $(10 \mathrm{~L})$ containing moist soil obtained from the topsoil (ca. $0-20 \mathrm{~cm}$ in depth) of a soybean crop located in Dois Vizinhos, Paraná, Brasil. Each pot contained five soybean plants,. and they were kept in a greenhouse until the beginning of the experiment $\left(25 \pm 2^{\circ} \mathrm{C}\right)$. The experiment was performed when plants reached phenological phase V6. The treatments used were: T1: acibenzolar-S-Methyl (ASM-0.005\%); T2: salicylic acid (AS-2 Mm); T3: phosphite Potassium (ULTRA K®-0.004\%); T4: chitosan (CH-1\%); T5: silicon (SI-0.25\%); T6: control group (distilled water)-challenged and not challenged by B. tabaci. The treatments were sprayed over the above ground part of the plant. The vases were kept individually in cages with anti-aphid screens. For treatments that plants were challenged by B. tabaci, 50 adult flies were added per cage, collected from the field. The experimental design was completely randomized in a two-by-two factorial design, the factors being the treatments and the presence or absence of $B$. tabaci with five replicates per treatments.

For biochemical analysis (total proteins, total and reduced sugars, phenolic compounds and the activity of enzymes related to plant defense-peroxidase (PO), phenylalanine ammonia-lyase (PAL), chitinase and $\beta$-1,3-glucanase), plant tissue $(0.5 \mathrm{~g})$, were collected at intervals of $0,24,48,96$ and 168 hours after application of the elicitors. Samples were frozen and stored in liquid nitrogen. All biochemical analyses were performed according to classical methodology: Protein content (Bradford, 1976); PAL (Kuhn, 2007). PO and phenolic compounds (Matsuno \& Uritani, 1972). Otal soluble sugars (Dubois et al., 1956); Reducing sugars (Miller, 1959). The concentration of reducing sugars was calculated as a function of the standard glucose curve.

For quantification of chitinase and $\beta$-1,3-glucanase activities, the samples were macerated in $4.0 \mathrm{~mL}$ of $100 \mathrm{mM}$ acetate buffer ( $\mathrm{pH} 5.0$ ), with subsequent centrifugation $\left(20,000 \mathrm{~g}\right.$ for $25 \mathrm{~min}$ at $-4{ }^{\circ} \mathrm{C}$ ). The supernatant was collected and used for the evaluation of enzyme activity. The enzymatic activity of chitinase was assessed by the release of soluble "CM-chitin-RBV" fragments from carboxymethylated chitin labeled with RBB-Remazol Brilant Blue. The readings were performed with a spectrophotometer $(595 \mathrm{~nm})$. For quantification of $\beta$-1,3-glucanase $(600 \mathrm{~nm})$, bright blue carboxymethylcurdlan-remazol solution (CM-Curdlan-RBB $4 \mathrm{mg} / \mathrm{ml}$, Loewe Biochemica $\mathrm{GmbH}$ ) was used as substrate, according to a methodology developed by Wirth and Wolf (1992) and with the procedure described by Guzzo and Martins (1996).

The collected data were submitted to ANOVA $(p \leq 0.05)$ and presented as descriptive statistics (mean \pm standard deviation) and regression analysis $(p \leq 0.05)$ by the Assistat ${ }^{\circledR}$ program (Silva \& Azevedo, 2009).

\section{Results and Discussion}

\subsection{Proteins Activity}

There was a significant interaction between the factors evaluated in the experiment. The activity of proteins was affected both by the treatments and by time. As observed in Figure 1, there were alterations in protein synthesis, since the measured values presented variation in relation to the application of the inductors and the attack of the whiteflies. In general, the highest activation occurred at 96 hours, both with the presence and absence of insects.

Proteins are polymers formed by amino acids and are the most abundant macromolecules in plant tissue. Proteins present structural and dynamic functions; some proteins are enzymatic catalysts, participating in several biochemical reactions; and some, are precursors for many secondary metabolites involved in local and systemic responses (Zhou et al., 2015).

At 168 hours, an increase in protein levels was observed, including in the control. This reason can be explained by the plant's ability to release volatile organic compounds (VOCs), a way of signaling non-elicited plants. In addition to direct action on induction of resistance, they may act indirectly attracting predators of herbivores (Heil, Bueno, 2007). 

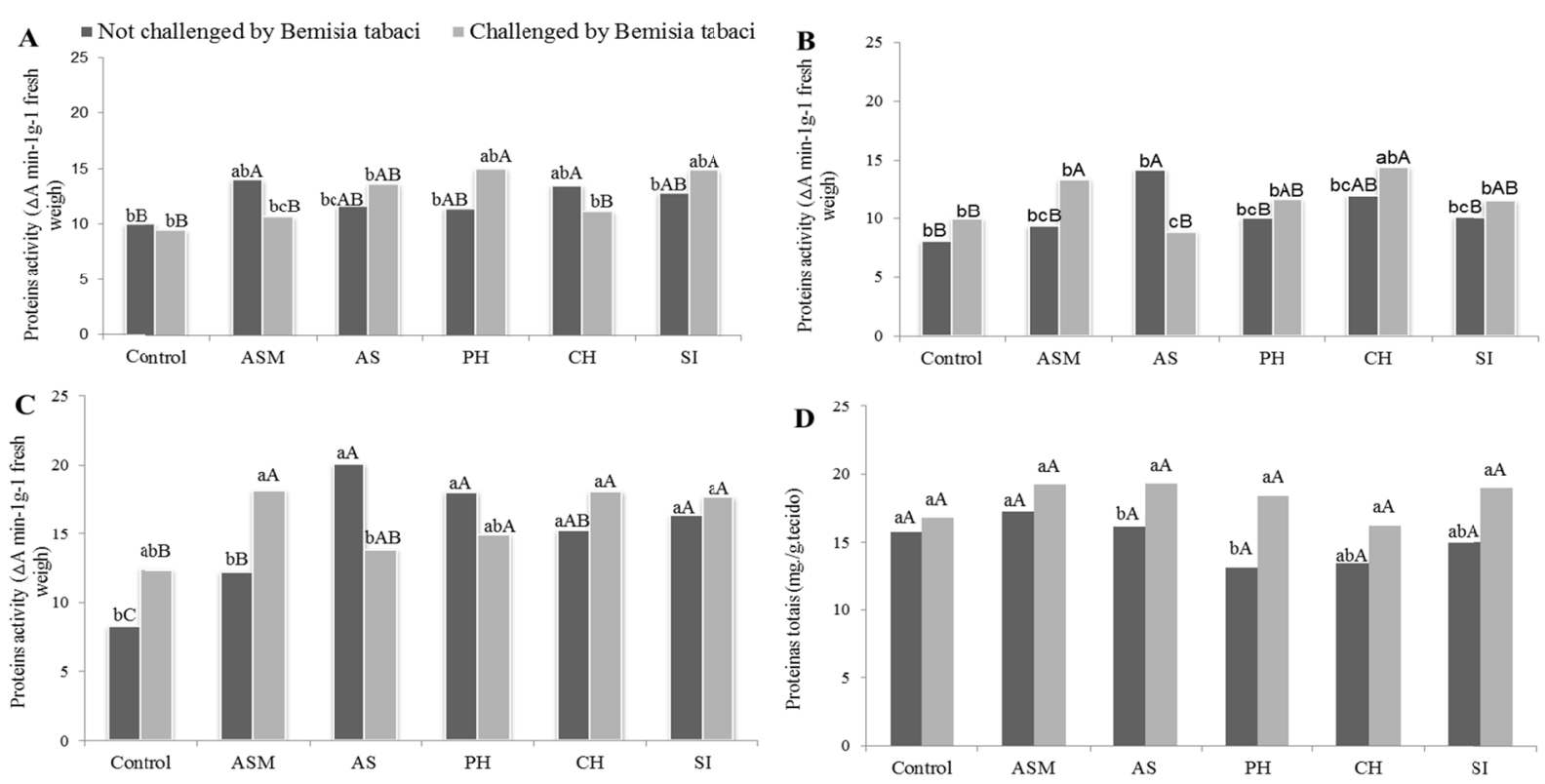

Figure 1. Proteins activity $\left(\triangle \mathrm{A} \min ^{-1} \mathrm{~g}^{-1}\right.$ fresh weigh) in soybean plants in the phenological stage V6 sprayed with resistance elicitors challenged by Bemisia tabaci. A) after 24 hours of application; B) after 48 hours; C) after 96 hours; D) after 168 hours

Note. ${ }^{1}$ Means followed by the same lowercase vertical letter, or upper case horizontal, are not significantly different by Tukey's test, at the $(\mathrm{p} \leq 0.05)$ error probability level. The elicitors acibenzolar-S-Methyl (ASM), Salicylic Acid (SA), Foliar phosphite (PH), Chitosan (CH) and Silicon (SI)

Plants that are attacked by herbivores, fungi or present wounds, produce induced defense with (VOCs) produced by enzymes, being transferred by signs and events of transduction to other neighboring plants or leaves that respond to this signaling as a defense (Wang et al., 2015). Many VOC mixtures are produced "on demand" after mechanical or biological challenge, and their composition depends on the mode of injury, such as wounds (Mithöfer, Wanner, \& Boland, 2005), egg deposition (Hilker \& Meiners, 2006) and herbivores feeding (Mithöfer \& Boland, 2012).

Volatiles induced after herbivores attack appear to "prepare" neighboring plants for a possible future attack. Little is known about the herbivore defense mechanisms in soybean and the interaction of VOCs in plant defense, however, it is clear that the type of food damage clearly affects the VOCs produced, and part of the biochemical explanation is that leaf chewers in general induce only signaling of jasmonic acid, while sucking herbivores tend to induce salicylic acid mediated resistance pathways (Smith \& Boyko, 2007).

In addition to the natural elicitors, it is important to mention that the emission of volatiles by the plant can be induced by the exogenous application of plant hormones such as jasmonic acid and salicylic acid, as well as other elicitors of microbial origin (Ton, 2007). Thus, indirect defense mediated by the herbivore-induced release of VOCs has received the most attention.

For reducing sugars (glucose, fructose, maltose) and total sugars (glucose, fructose, mannose and sucrose), there was no difference amongstthe treatments; with values varying between 0.0008 and $0.0013 \mathrm{mg} / \mathrm{g}$ plant tissue for reducing sugars and between 58.54 and $96.21 \mathrm{mg} / \mathrm{g}$ plant tissue for total sugars, respectively.

The activation of specific responses requires recognition and appropriate response towards the attacking enemy. Possibly, the activations of the plant defense mechanisms did not demand defense compounds have low molecular weight, and with this low energy demand for their synthesis. However, the results demonstrated that resistance inducers did acted on the plant primary metabolism by activating protein synthesis.

\subsection{Phenylalanine Ammonia-lyase (PAL) Activity}

The results show that the inducers activated the route of the phenylpropanoids, observed by PAL activity. In the presence of insects, the highest activation occurred after 96 hours. In the absence of insects, the activation was with 168 hours with the application of all elicitors, demonstrating the elicitors' later response to the attack itself. 
The PAL is a key enzyme relevant to secondary metabolism, responsible for the deamination of L-phenylalanine to form trans-cinnamic acid and later several phenolic compounds, such as 4-coumarium acid, caffeic acid and synaptic acid (Tauzin \& Gardard, 2014). It is also a key enzyme in salicylic acid (SA) biosynthesis (Wang et al., 2015). The route of phenylpropanoids feeds several metabolic pathways, which generate different compounds such as lignin, flavonoids, phytoalexins, and tannins. Thus, the increase of the concentration of a certain phenolic compound may occur and the FAL activity remains unchanged (Kofalvi \& Nassuth, 1995).
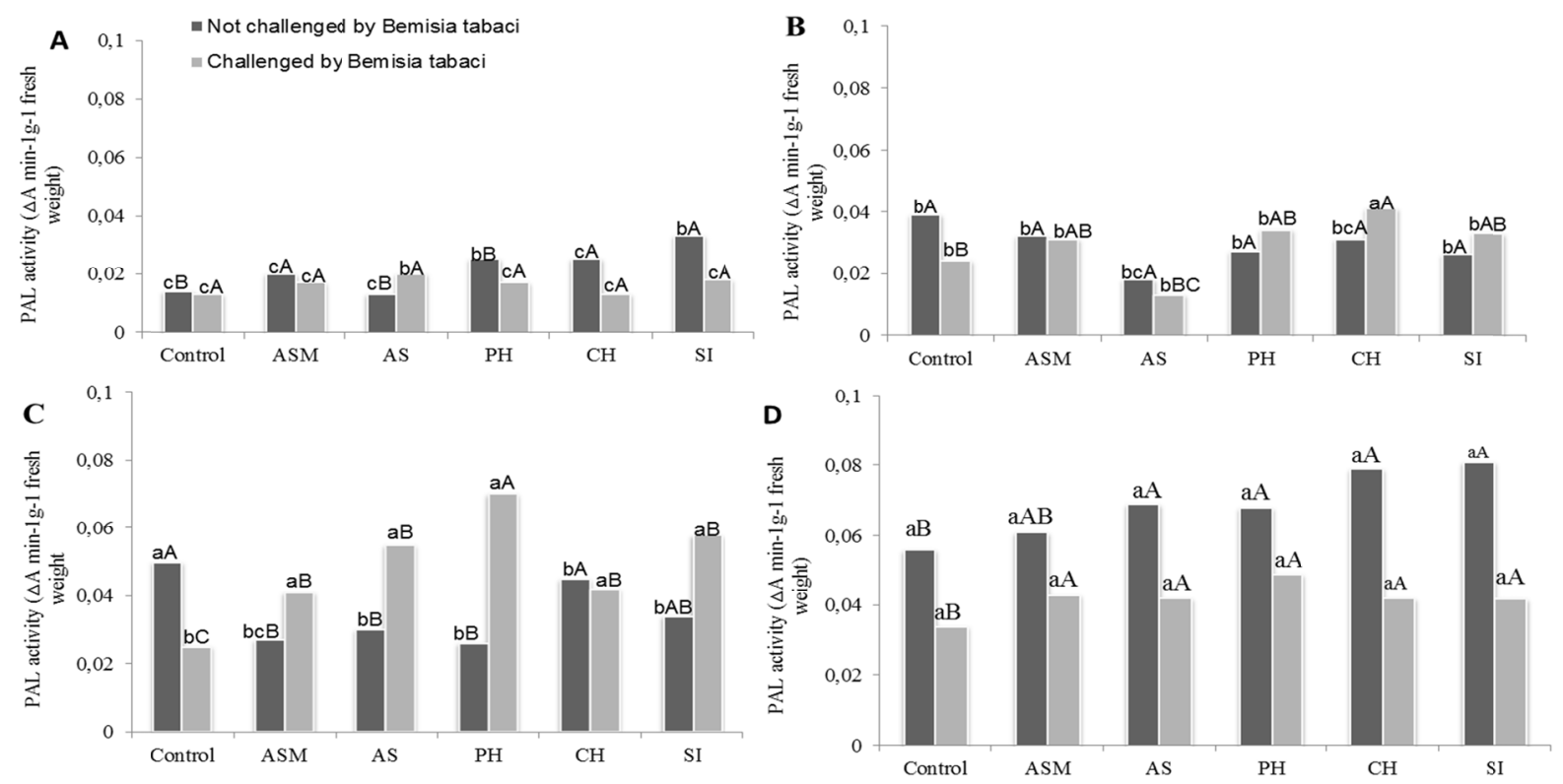

Figure 2. Phenylalanine ammonia-lyase (PAL) activity $\left(\triangle \mathrm{A} \min ^{-1} \mathrm{~g}^{-1}\right.$ fresh weight) in soy plants in the phenological stage V6 sprayed with resistance elicitors challenged by Bemisia tabaci. (A) after 24 hours of application; (B) after 48 hours; (C) after 96 hours; (D) after 168 hours

Note. ${ }^{2}$ Means followed by the same lowercase vertical letter, or upper case horizontal, are not significantly different by Tukey's test, at the $(\mathrm{p} \leq 0.05)$ error probability level. The elicitors acibenzolar-S-Methyl (ASM), Salicylic Acid (SA), Foliar phosphite (PH), Chitosan (CH) and Silicon (SI).

After 24 hours, it has been observed that the elicitors $\mathrm{PH}, \mathrm{CH}$, and $\mathrm{SI}$ are more effective in the activation of the PAL. At 48 hours, an inversion of this activation occurs, that is, the vegetable responds more efficiently to the insect attack because the imminent damage was detected. The analyzes performed at $96 \mathrm{~h}$, also show a more pronounced PAL activity in the exclusive insect treatments compared to the inducers. However, at $168 \mathrm{~h}$, the effectiveness of all resistance inducers is evident, again demonstrating its later action, especially CH and SI. In this way, treatments with $\mathrm{CH}$ and SI were more effective in initial and later responses, promoting a better defense to the vegetable.

The activation conferred by the application of the plants by silicon may be due to its accumulation and polymerization in the cells, forming a mechanical barrier that makes it difficult to attack pests and pathogens (Epstein, 2001). Gomes et al. (2005) suggested that silicon acts as the elicitor of the resistance mechanism induced in wheat plants.

Chitosan, as a reference/standard inducer, as already observed by Mazaro et al. (2008), induced phytoalexins and PAL activity in soybean cotyledons. Chitosan is the acetylated form of chitin, a naturally occurring biopolymer as a component of fungal cell walls, insect exoskeletons, and crustacean shells. The characterization and the application of chitosan are already carried out in several works, showing potential in several sectors, including agriculture, industry, and medicine (Pichyangkura \& Chadchawan, 2015).

By injuring plant tissues, pectin fragments of oligogalacturonides in the cell wall induce the accumulation of reactive oxygen species (ROS) and proteins related to pathogenesis (PRPs) to protect plant tissues against infection by pathogens (Ferrari et al., 2013). Chitosan when exogenously applied in plant tissues triggers similar responses (Malerba \& Cerana, 2015). Chitosan can activate several defense responses in the plant tissue, causing: 
lignification, induction of callus synthesis, elicitation of phytoalexin production, hydrogen peroxide $\left(\mathrm{H}_{2} \mathrm{O}_{2}\right)$, chitinase accumulation, synthesis of inhibitors of proteinase (El hadrami, 2010), induces stomatal closure via $\mathrm{H}_{2} \mathrm{O}_{2}$ signaling (Lee et al., 1999).

Working with plant extracts, Lorencetti et al. (2015) verified high values of PAL activity and insecticidal effect against the brown bug Thaumastocoris peregrinus. The same can be verified in the work Freire (2015), which observed greater activation of PAL in soybean when the interaction of the nematoid with the ASM inductor occurred. Almeida et al. (2012) verified the highest activation of PAL in 168 hours in soybean when inoculated with $P$. pachyrhizi fungus. However, Gomes et al. (2008) analyzed the application and silicon foliar application in the potato crop against Myzus persicae, where it did not affect PAL activity, but there was an increase in lignin and tannin content, making the plants more resistant to pests.

\subsection{Phenolic Compounds}

As observed in figure 3, there was activation of the route for phenolic compounds both in the exclusive treatments with inducers and in the presence of insects. Demonstrates the importance of the elicitors, who act in a similar way to an attack, however, without causing damage to the plant. Can also be observed in the control, since in the absence of the inductors the response was smaller in comparison to the attack of the flies. The gradual increase of phenolic compounds in the control (without the flies) may be related to communication between plants. In general, all the inducers activated the synthesis of phenolic compounds, especially in a later response (Figure 3D).
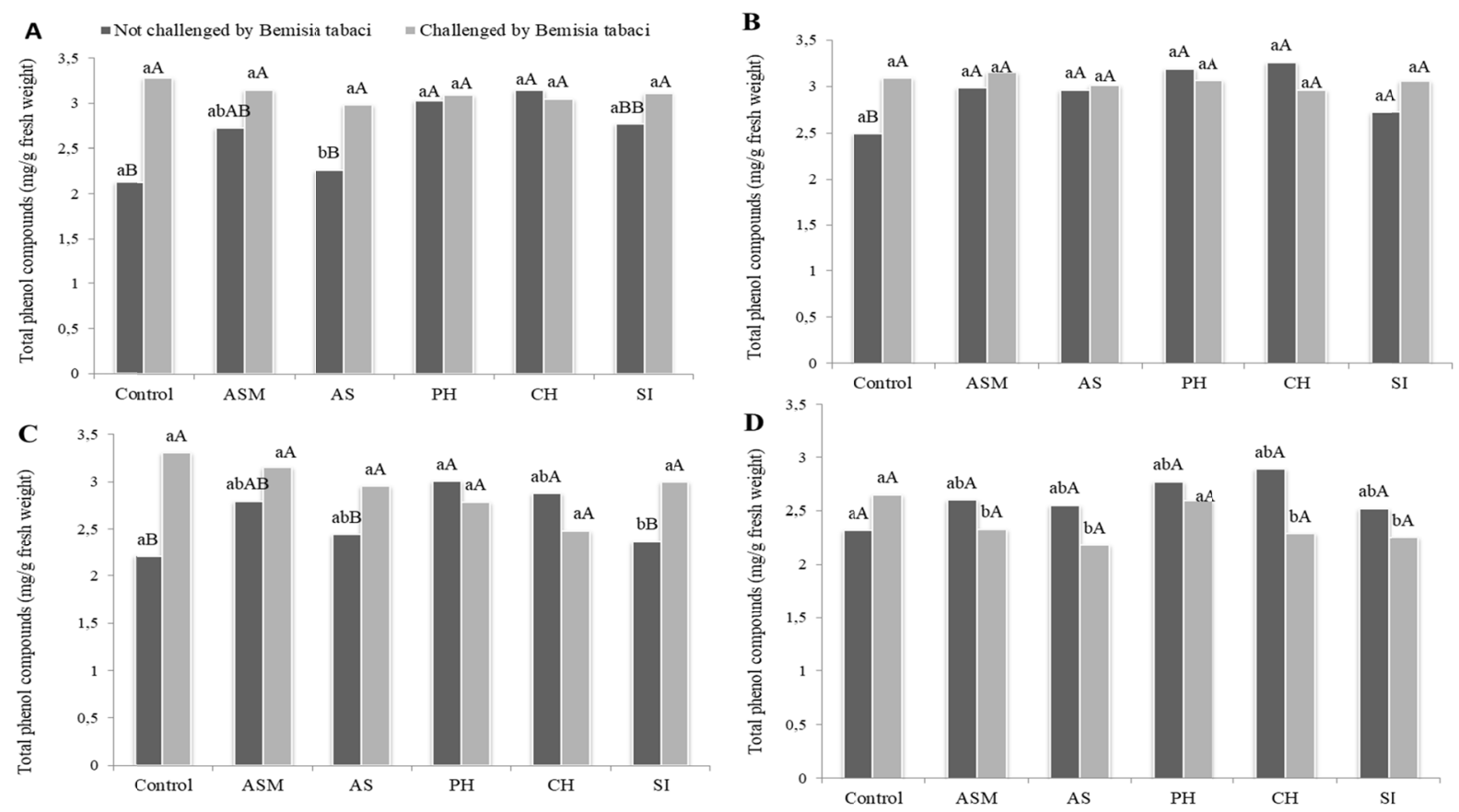

Figure 3. Total phenol compounds ( $\mathrm{mg} / \mathrm{g}$ fresh weight) in soy plants in the phenological stage V6 sprayed with resistance elicitors challenged by Bemisia tabaci. (A) after 24 hours of application; (B) after 48 hours; (C) after 96 hours; (D) after 168 hours

Note. ${ }^{2}$ Means followed by the same lowercase vertical letter, or upper case horizontal, are not significantly different by Tukey's test, at the $(\mathrm{p} \leq 0.05)$ error probability level. The elicitors acibenzolar-S-Methyl (ASM), Salicylic Acid (SA), Foliar phosphite (PH), Chitosan (CH) and Silicon (SI).

There are approximately 10,000 groups of phenols with heterogeneous compounds, being synthesized by the route of the chiquimic acid and route of the malonic acid. Due to the great variety, they present diverse functions from defense against herbivores, mechanical support and protection against radiation (Taiz \& Zeiger, 2017).

Phenolic compounds are directly linked to the expression of the peroxidase route, which participate in several physiological processes of great importance in the plant, such as lignification. In this process the phenols are oxidized by the action of hydrogen peroxide and polymerized to form lignin. Lignin is deposited on the cell wall 
and responsible for wall stiffening and increased resistance to attack by external agents (Strack, 1997). The lignification of the cells comprises an important mechanical barrier to the penetration of insects and pathogens.

For the authors Ferreira, Moraes, and Antunes (2011) there wasn't a significant effect on the phenol content of silicon in two soybean cultivars: IAC-19 and MONSOY-8001 against $B$. tabaci. The same was verified by Pinto et al. (2012) in the cacao against the aphid Toxoptera aurantii.

The reduction of the phenolic compounds content by the ASM inducer was observed by Kuhn and Pascholati (2010) in the bean leaves after the second application (21 days after starting the treatment). However, Guimarães et al. (2008) observed increase of phenols in sugarcane plants when submitted to infestation of Mahanarva fimbriolata.

\subsection{Peroxidase Activity}

The application of the inductors, both presence and absence of the insects, promoted the activation of the enzyme peroxidase as observed in Figure 4. It is evident that in the first $24 \mathrm{~h}$ (Figure 4A) the activation of the enzyme is strongly influenced by the insect, but in the course of time (Figure 4D) elicitors play a key role in the synthesis of this enzyme, mainly ASM and PH.

These results demonstrate the potential of products to activate defense mechanisms. A differentiated behavior was observed in peroxidase activation, which demonstrates a specificity regarding the inductors and activation time. This fact is related to the diversity of routes and compounds in which the peroxidase may be involved, among them the synthesis of several compounds of defense, may be structural such as lignin or water-soluble metabolites.
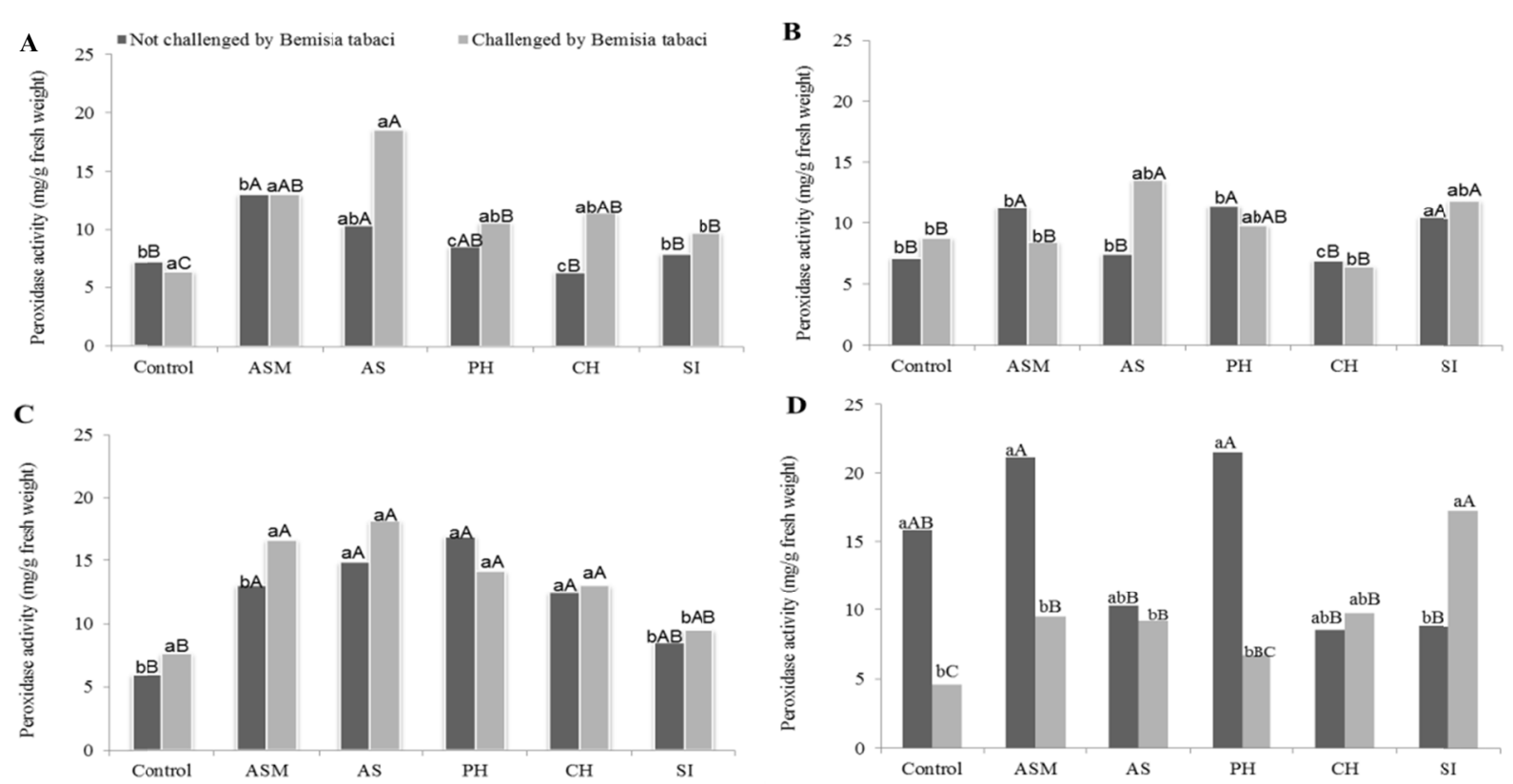

Figure 4. Peroxidase activity ( $\mathrm{mg} / \mathrm{g}$ fresh weight) in soy plants in the phenological stage V6 sprayed with resistance elicitors challenged by Bemisia tabaci. A) after 24 hours ofapplication; B) after 48 hours; C) after 96 hours; D) after 168 hours

Note. ${ }^{3}$ Means followed by the same lowercase vertical letter, or upper case horizontal, are not significantly different by Tukey's test, at the $(\mathrm{p} \leq 0.05)$ error probability level. The elicitors acibenzolar-S-Methyl (ASM), Salicylic Acid (SA), Foliar phosphite (PH), Chitosan (CH) and Silicon (SI).

The increase of this enzyme is observed when plants are challenged by external agents, such as pathogens, insects or when plants are subjected to stress. In this work, soybeans activated the self-defense system in response to the insect's injuries in order to protect itself.

A similar fact was observed in the work of Tscharntke et al. (2001) by the leaf beetle Agelastica alni (Coleoptera: Chrysomelidae) on alder leaves. However, Couto et al. (2009) observed that controls not inoculated with Fusarium oxysporum f.sp. vasinfectum W.C demonstrated high enzyme levels. For Gomes et al. (2008), this work was carried out to evaluate the action of silicon as a resistance inducer of potato to Myzus persicae (Sulzer), four 
treatments were tried: foliar fertilization with silicon acid at $1 \%$; soil fertilization with $250 \mathrm{ml}$ silicic acid solution at $1 \%$; foliar fertilization with silicon acid at $1 \%+$ soil fertilization with $250 \mathrm{ml}$ silicic acid solution at $1 \%$; and a control. The results show the lignin percentage increased in the leaves of plants fertilized with silicon via soil and/or foliar and the percentage of tannins increased only in the leaves fertilized via soil plus foliar. The silicon acted as a resistance inducer to $M$. persicae in potato.

Peroxidases are the only enzymes that polymerize the alcohols in lignin, being present in lignified plant cells. They also participate in the oxidation of indole acetic acid (AIA) and phenolic compounds (3). Lignin, in addition to cellulose and other polysaccharides that occur in the cell wall of the upper plants, works as a physical barrier and acts to heal wounds caused by fungi and insects (Gaspar et al., 1982; Kao, 2003).

Both stressors (phytopathogen and insect) when they attack the plants make them respond quickly with an "oxidative explosion", which constitute the production of reactive oxygen species (ROS), mainly superoxide anion $\left(\mathrm{O}_{2}{ }^{-}\right)$and peroxide of hydrogen $\left(\mathrm{H}_{2} \mathrm{O}_{2}\right)$ (Hu et al., 2009). The accumulation of these substances in plant cells can be toxic to both (plant and stressors). The $\mathrm{H}_{2} \mathrm{O}_{2}$ is the main reactive oxygen species that activates molecules for the induction of defense genes and the polymerization of proteins that make up the cell wall (Lukasik et al., 2012).

The herbivory has been linked to changes in intracellular EROs and in peroxidase activity in plants and the largest group of insects studied corresponds to hemiptera (Torres, 2010; War et al., 2012). War et al. (2011) analyzed the peroxidase activity of three peanut genotypes (Arachis hypogaea L.) in response to feeding of Spodoptera litura (Fab.) (Lepidoptera: Noctuidae) and observed that there was an increase in the activity of this enzyme at 96 hours after infestation.

It is evident that the peroxidases play an important and dinamino role in defense against the attack of insect pests. Peroxidases have the potential to be used as markers for selecting insect resistant turfgrasses, and may help explain how plants defend themselves against biotic stresses, such a tolerant plant's defense response to insect feeding, including the signaling of plant defense reactions to injury, efficient removal of reactive oxygen species, or both.

\subsection{Chitinase Activity}

The chitinase levels had interference when the elicitors were applied, and with absence of the insects the activation was pronounced with 168 hours. When the plants were challenged with the inductors and the presence of the insects, there was activation from 48 hours for all the inductors except for the phosphite with 168 hours.

These results demonstrate that when the inductors are applied with the presence of the insect, the preferential defense mechanism activated is the chitinases, a fact that can be explained by the presence of chitin in the exoskeleton of the insects, acting in the process of signaling and expression of this hydrolytic enzyme in plant defense. Factor that also indicates the non-expression of glucanases.

Activation in the presence of the insect may also be linked to another form of plant recognition, as they may recognize specific components in insect saliva. Most plant responses to insects involve the response to both injury and the recognition of certain compounds abundant in insect saliva or regurgitation. These compounds belong to the group of molecules called elicitors. For insect-derived elicitors, the molecular patterns associated with herbivores are HAMPs (herbivore associated molecular patterns) and effectors, which directly and indirectly influence plant defense (Taiz \& Zeiger, 2017). 

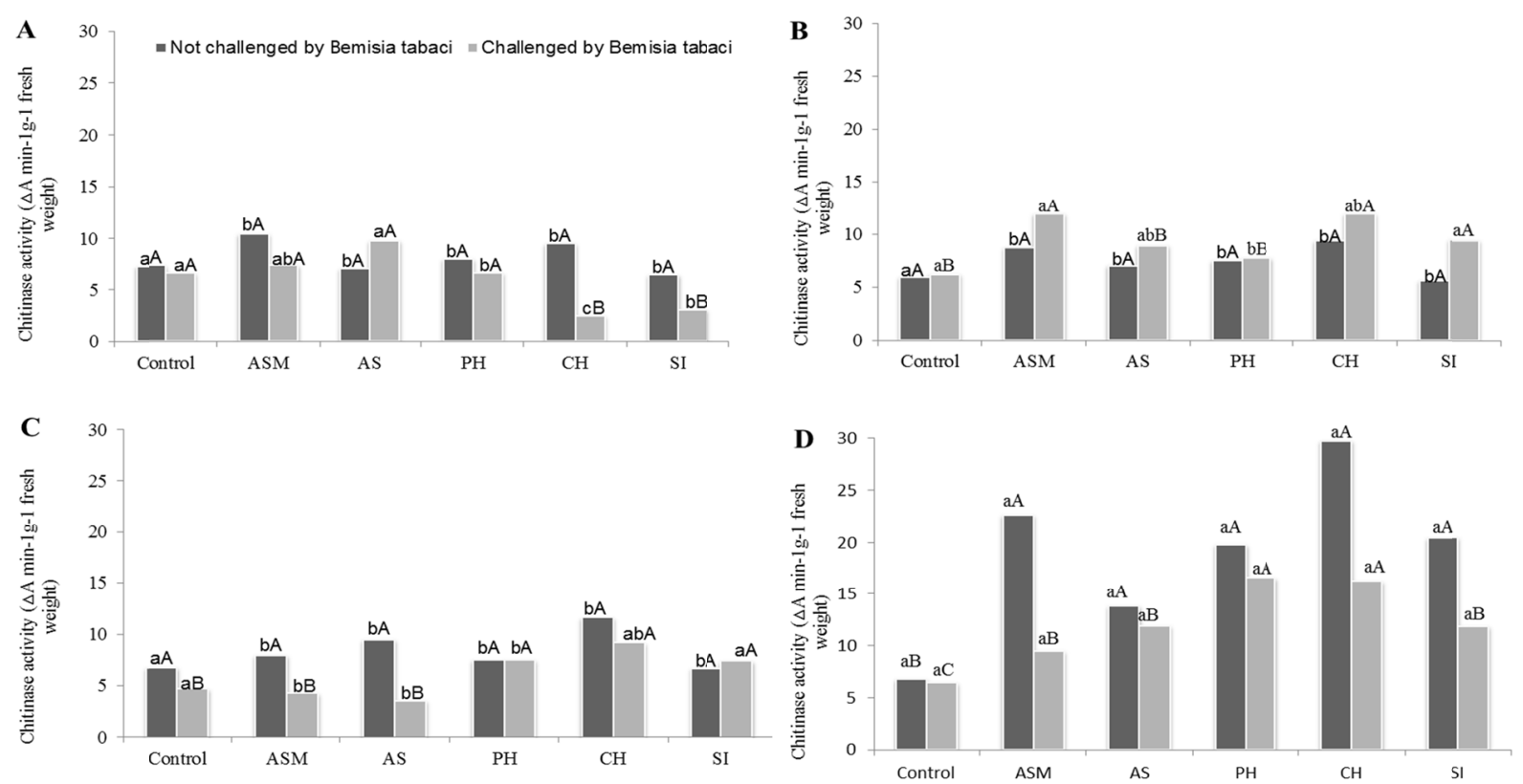

Figure 5. Chitinase activity ( $\triangle \mathrm{A} \mathrm{min}^{-1} \mathrm{~g}^{-1}$ fresh weight) in soy plants in the phenological stage $\mathrm{V} 6$ sprayed with resistance elicitors challenged by Bemisia tabaci. A) after 24 hours of application; B) after 48 hours; C) after 96 hours; D) after 168 hours

Note ${ }^{4}$ Means followed by the same lowercase vertical letter, or upper case horizontal, are not significantly different by Tukey's test, at the $(\mathrm{p} \leq 0.05)$ error probability level, The elicitors acibenzolar-S-Methyl (ASM), Salicilic Acid (SA), Foliar phosphite (PH), Chitosan (CH) and Silicon (SI).

Among the most studied PR proteins are the chitinases (PR-3) and $\beta-1,3$ glucanases (PR-2), both with hydrolytic activity, depolymerizing structural saccharides present in the wall of pathogens (Cavalcanti, Brunelli, \& Stangarlin, 2006). Enzymes can act alone or in synergism (Kombrink \& Somssich, 1997).

Couto et al. (2009) evaluated chitinase activity in cotton plants with and without Fusarium oxysporum inoculation, and both treatments did not differ significantly with the ASM and potassium phosphite inducers, but in the MeJ (methyl jasmonate) treatment, they verified chitinase activity in leaf. The same can be verified by Tavares et al. (2010), in which the ASM did not induce the chitinase activity in papaya against fungus $P$. palmivora.

Most studies on the response of plants to insect food injury focus on the induction of protease inhibitors. There are few studies on the effect of insects on the induction of PR proteins as demonstrated in this work. Studies are also needed to elucidate whether plant induction and the use of synthetic compounds have any effect on natural enemies, and non-target organisms.

The use of synthetic inducers offers many advantages, since they reduce the investment in insecticides, delay adaptation and resistance development of herbivores, and do not harm the environment. In the general context, it is imperative to carry out research in these areas and develop new strategies and technologies for sustainable management and to be used in pest control in agriculture.

\section{Conclusion}

Resistance inducers have the ability to activate the primary metabolism through the synthesis of total proteins, as well as demonstrate the potential in the activation of defense mechanisms among them, the route of the phenylpropanoides with the activation of the PAL enzyme and the formation of phenolic compounds. They also demonstrate the activation of pathogenicity-related enzymes such as peroxidases and chitinase, and such activations have specificity for inducer and activation time.

\section{References}

Almeida, H. O., de Oliveira Barbosa, M., Marques, A. E., Pereira, T. H. A., Júnior, M. J. M., Tessarollo, N. G., \& Abdelnoor, R. V. (2012). Enzimas marcadoras de indução de resistência diferencialmente reguladas em soja resistente e suscetível à ferrugemasiáticadasoja. Pesquisa Agropecuária Brasileira, 47(2), 163-172. https://doi.org/10.1590/S0100-204X2012000200003 
Bieleski, R. L., \& Turner, N. A. (1966). Separation and estimation of amino acids in crude plant extratcts by thin-layer electrophoresis and chomatograghy. Analitycal Biochemistry, 17, 278-293. https://oi.org/10.1016/ 0003-2697(66)90206-5

Bôas, G. L. V., \& Branco, M. C. (2009). Manejo Integrado da Mosca-Branca (Bemisia tabaci biótipo B) em Sistema de Produção Integrada de Tomate Indústria (PITI). Embrapa Hortaliças (Circular Técnica 70). Brasília, DF.

Bradford, M. M. (1976). A rapid and sensitive method for the quantification of microgram quantities of protein utilizing the principle of protein-dye binding. Analytical Biochemistry, 72, 248-254. https://oi.org/10.1016/ 0003-2697(76)90527-3

Cavalcanti, F. R., de Resende, M. L. V., Pereira, R. B., \& da Silveira Carvalho, C. P. (2006). Atividades de quitinase e beta-1,3-glucanase após eliciação das defesas do tomateiro contra a mancha-bacteriana. Pesquisa Agropecuária Brasileira, 41(12), 1721-1730. https://doi.org/10.1590/S0100-204X2006001200006

Couto, E. F., Coelho, R. S., Suassuna, N. D., \& Oliveira, S. M. (2009). Avaliação de indutores de resistência em algodoeiro a murcha de fusário: atividade enzimática e índice de infecção. Tropical Plant Pathology, 34(4), 352-356. https://doi.org/10.1590/S1982-56762009000500011

CONAB (Companhia Nacional de Abastecimento). (2018). Acompanhamento da safra brasileira de grãos. v.12, safra 2017/2018, décimo segundo levantamento (p. 148). Brasília: CONAB.

Cruz, M. F. A., Diniz, A. P. C., Rodrigues, F. A., \& de Barros, E. G. (2011). Aplicação foliar de produtos na redução da severidade da brusone do trigo. Tropical Plant Pathology, 36, 424-428. https://doi.org/10.1590/ S1982-56762011000600014

Dalastra, C., Campos, A. R., Fernandes, F. M., Martins, G. L. M., \& Campos, Z. R. (2011).Silício como indutor de resistência no controle do tripes do prateamento Enneothrips flavens Moulton, 1941 (Thysanoptera: Thripidae) e seus reflexos na produtividade do amendoinzeiro. Ciência e Agrotecnologia, 531-538. https://doi.org/10.1590/S1413-70542011000300014

Dalton, R. (2006). Whitefly infestations: The Christmas invasion. Natureza, 443, 898-900. https://doi.org/ $10.1038 / 443898 \mathrm{a}$

Dubois, M., Gilles, K. A., Hamilton, J. K., Rebers, P. A., \& Smith, F. (1956). Colorimetric method for determination of sugars and related substances. Anal. Chem., 28, 350-356. https://doi.org/10.1021/ ac60111a017

El Hadrami, A., Adam, L. R., El Hadrami, I., \& Daayf, F. (2010). Chitosan in plant protection. Marine drugs, 8(4), 968-987. https://doi.org/10.3390/md8040968

Epstein, E. (2001). Silicon in plants: Facts vs. concepts. Studies in Plant Science, 8, 1-15. https://oi.org/10.1016/ S0928-3420(01)80005-7

Ferrari, S., Savatin, D. V., Sicilia, F., Gramegna, G., Cervone, F., \& De Lorenzo, G. (2013). Oligogalacturonides: Plant damage-associated molecular patterns and regulators of growth and development. Frontiers in Plant Science, 4, 49. https://doi.org/10.3389/fpls.2013.00049

Ferreira, R. S., \& Moraes, J. C. (2011). Silicon influence on resistance induction against Bemisia tabaci biotype B (Genn.) (Hemiptera: Aleyrodidae) and on vegetative development in two soybean cultivars. Neotropical Entomology, 40(4), 495-500. https://doi.org/10.1590/S1519-566X2011000400014

Freire, L. L. (2015). Indução de resistência de cultivares de soja a Pratylenchus brachyurus (65 f., Dissertação (Mestrado em Agronomia), Universidade Federal de Goiás).

Gomes, F. B., Moraes, J. C. D., Santos, C. D. D., \& Goussain, M. M. (2005). Resistance induction in wheat plants by silicon and aphids. Scientia Agricola, 62(6), 547-551. https://doi.org/10.1590/S0103-9016200500 0600006

Gomes, F. B., Moraes, J. C., Santos, C. D. D., \& Antunes, C. S. (2008). Use of silicon as inductor of the resistance in potato to Myzus persicae (Sulzer) (Hemiptera: Aphididae). Neotropical Entomology, 37(2), 185-190. https://doi.org/10.1590/S1519-566X2008000200013

Guimarães, E. R., Mutton, M. A., Mutton, M. J. R., Ferro, M. I. T., Ravaneli, G. C., \& Silva, J. A. D. (2008). Free proline accumulation in sugarcane under water restriction and spittlebug infestation. Scientia Agricola, 65(6), 628-633. https://doi.org/10.1590/S0103-90162008000600009 
Gulsen, O., Eickhoff, T., Heng-Moss, T., Shearman, R., Baxendale, F., Sarath, G., \& Lee, D. (2010). Characterization of peroxidase changes in resistant and susceptible warm-season turfgrasses challenged by Blissus occiduus. Arthropod-Plant Interactions, 4(1), 45-55. https://doi.org/10.1007/s11829-010-9086-3

Guzzo, S. D., \& Martins, E. M. F. (1996). Local and systemic induction of $\beta$-1,3-glucanase and chitinase in coffee leaves protected against Hemileia vastatrix by Bacillus thuringiensis. J Pathol, 144, 449-454. https://doi.org/ 10.1111/j.1439-0434.1996.tb00322.x

Heil, M., \& Bueno, J. C. S. (2007). Herbivore-induced volatiles as rapid signals in systemic plant responses: how to quickly move the information. Plant Signaling \& Behavior, 2(3), 191-193. https://oi.org/10.4161/ psb.2.3.4151

Hilker, M., \& Meiners, T. (2006). Early herbivore alert: insect eggs induce plant defense. Journal of Chemical Ecology, 32(7), 1379-1397. https://doi.org/10.1007/s10886-006-9057-4

Hsu, S. Y., \& Kao, C. H. (2003). Differential effect of sorbitol and polyethylene glycol on antioxidant enzymes in rice leaves. Plant Growth Regulation, 39(1), 83-90. https://doi.org/10.1023/A:1021830926902

Hu, Z. H., Shen, Y. B., Shen, F. Y., \& Su, X. H. (2009). Effects of feeding Clostera anachoreta on hydrogen peroxide accumulation and activities of peroxidase, catalase, and ascorbate peroxidase in Populus simonii $\times$ P. pyramidalis 'Opera 8277' leaves. Acta Physiologiae Plantarum, 31(5), 995-1002. https://doi.org/10.1007/ s11738-009-0316-1

Jennings, A. C. (1991). The determination al dihydroxy phenolic compounds in extracts of plant tissues. Analitycal Biochemistry, 118, 396-398. https://doi.org/10.1016/0003-2697(81)90600-X

Kofalvi, S. A., \& Nassuth, A. (1995). Influence of wheat streak mosaic virus infection on phenylpropanoid metabolism and the accumulation of phenolics and lignin in wheat. Physiological and Molecular Plant Pathology, 47(6), 365-377. https://doi.org/10.1006/pmpp.1995.1065

Kuhn, O. J. (2007). Indução de resistência em feijoeiro (Phaseolus vulgaris) por acibenzolar-S-metil e Bacillus cereus: aspectos fisiológicos, bioquímicos e parâmetros de crescimento e produção (p. 140). Piracicaba: Escola Superior de Agricultura Luiz de Queiroz, Universidade de São Paulo.

Kuhn, O. J., \& Pascholati, S. F. (2010). Custo adaptativo da indução de resistência em feijoeiro mediada pela rizobactéria Bacillus cereus ou acibenzolar-S-metil: atividade de enzimas, síntese de fenóis e lignina e biomassa. Summa Phytopathologica, 36(2), 107-114. https://doi.org/10.1590/S0100-54052010000200001

Li, Q., Xie, Q. G., Smith-Becker, J., Navarre, D. A., \& Kaloshian, I. (2006). Mi-1-mediated aphid resistance involves salicylic acid and mitogen-activated protein kinase signaling cascades. Molecular Plant-Microbe Interactions, 19(6), 655-664. https://doi.org/10.1094/MPMI-19-0655

Lorencetti, G. A. T., Mazaro, S. M., Potrich, M., Lozano, E. R., Barbosa, L. R., Luckmann, D., \& Dallacort, S. (2015). Produtos alternativos para controle de Thaumastocoris peregrinus e indução de resistência em plantas. Embrapa Florestas-Artigo em Periódico Indexado. https://doi.org/10.1590/2179-8087.066913

Łukasik, I., Goławska, S., \& Wójcicka, A. (2012). Effect of cereal aphid infestation on ascorbate content and ascorbate peroxidase activity in triticale. Pol J Environ Stud, 21, 1937-1941.

Malerba, M., \& Cerana, R. (2015). Reactive oxygen and nitrogen species in defense/stress responses activated by chitosan in sycamore cultured cells. International Journal of Molecular Sciences, 16(2), 3019-3034. https://doi.org/10.3390/ijms16023019

Matsuno, H., \& Uritani, I. (1972). Physiological behavior of peroxidase isozymes in sweet potato root tissue injured by cutting or with black rot. Plant and Cell Physiology, 23, 1091-1101.

Mazaro, S. M., Citadin, I., De Gouvêa, A., Luckmann, D., \& Guimarães, S. S. (2008). Indução de fitoalexinas em cotilédones de soja em resposta a derivados de folhas de pitangueira. Ciência Rural, 38(7). https://doi.org/ 10.1590/S0103-84782008000700004

Miller, G. L. (1959). Use of dinitrosalicylic and reagent for determination of reducing sugar. Analytical Chemistry, 31, 426-428. https://doi.org/10.1021/ac60147a030

Mithöfer, A., \& Boland, W. (2012). Plant defense against herbivores: Chemical aspects. Annual Review of Plant Biology, 63, 431-450. https://doi.org/10.1146/annurev-arplant-042110-103854 
Mithöfer, A., Wanner, G., \& Boland, W. (2005). Effects of feeding Spodoptera littoralis on lima bean leaves. II. Continuous mechanical wounding resembling insect feeding is sufficient to elicit herbivory-related volatile emission. Plant Physiology, 137(3), 1160-1168. https://doi.org/10.1104/pp.104.054460

Moraes, J. C., Ferreira, R. S., \& Costa, R. R. (2009). Indutores de resistência à mosca-branca Bemisia tabaci biótipo B (Genn., 1889) (Hemiptera: Aleyrodidae) em soja Ciência e Agrotecnologia, 33(5), 1260-1264. https://doi.org/10.1590/S1413-70542009000500009

Norman, J. W., Stansty, D. G., Ellsworth, P. A., \& Toscano, N. C. (1995). Management of sil verleaf whitefly: A comprehensive manual on the biology, economic impact and control tactics (No. C029.001). USDACSREES.

Oliveira, C. M., Auad, A. M., Mendes, S. M., \& Frizzas, M. R. (2014).Crop losses and the economic impact of insect pests on Brazilian agriculture. Crop Protection, 56, 50-54. https://doi.org/10.1016/j.cropro.2013. 10.022

Pichyangkura, R., \& Chadchawan, S. (2015). Biostimulant activity of chitosan in horticulture. Scientia Horticulturae, 196, 49-65. https://doi.org/10.1016/j.scienta.2015.09.03

Pinto, D. G., Aguilar, M. A. G., Souza, C. A. S., Silva, D. M., Siqueira, P. R., Cao, J. R., \& Zanetti, L. V. (2012). Physiological changes after application of silicon on cocoa and its influence on aphid preference. Revista Ceres, 59(3), 360-367. https://doi.org/10.1590/S0034-737X2012000300010

Pinto-Zevallos, D. M., Martins, C. B., Pellegrino, A. C., \& Zarbin, P. H. (2013). Compostos orgânicos voláteis na defesa induzida das plantas contra insetos herbívoros. Quim Nova, 36, 1395-1405. https://doi.org/10.1590/ S0100-40422013000900021

Smith, C. M., \& Boyko, E. V. (2007). The molecular bases of plant resistance and defense responses to aphid feeding: current status. Entomologia Experimentalis et Applicata, 122(1), 1-16. https://doi.org/10.1111/ j.1570-7458.2006.00503.x

Sticher, L., Mauch-Mani, B., \& Métraux, A. J. (1997). Systemic acquired resistance. Annual Review of Phytopathology, 35(1), 235-270. https://doi.org/10.1146/annurev.phyto.35.1.235

Taiz, L., \& Zeiger, E. (2017). Metabólitos secundários e defesa vegetal. Fisiologia Vegetal, 3, 309-344.

Tauzin, A. S., \& Giardina, T. (2014). Sucrose and invertases, a part of the plant defense response to the biotic stresses. Frontiers in Plant Science, 5, 293. https://doi.org/10.3389/fpls.2014.00293

Ton, J., D'alessandro, M., Jourdie, V., Jakab, G., Karlen, D., Held, M., ... Turlings, T. C. (2007). Priming by airborne signals boosts direct and indirect resistance in maize. The Plant Journal, 49(1), 16-26. https://doi.org/10.1111/j.1365-313X.2006.02935.x

Torres, M. A. (2010). ROS in biotic interactions. Physiologia Plantarum, 138(4), 414-429. https://doi.org/ 10.1111/j.1399-3054.2009.01326.x

Trouvelot, S., Héloir, M. C., Poinssot, B., Gauthier, A., Paris, F., Guillier, C., \& Adrian, M. (2014). Carbohydrates in plant immunity and plant protection: roles and potential application as foliar sprays. Frontiers in Plant Science, 5, 592. https://doi.org/10.3389/fpls.2014.00592

Tscharntke, T., Thiessen, S., Dolch, R., \& Boland, W. (2001). Herbivory, induced resistance, and interplant signal transfer in Alnus glutinosa. Biochemical Systematics and Ecology, 29(10), 1025-1047. https://doi.org/ 10.1016/0305-1978(01)00048-5

Walling, L. L. (2000). The myriad plant responses to herbivores. Journal of Plant Growth Regulation, 19(2), 195-216. https://doi.org/10.1007/s003440000026.

Wang, X., Chen, H., Shan, Z., Hao, Q., Zhang, C., Yang, Z., ... Jiao, Y. (2015). Herbivore defense responses and associated herbivore defense mechanism as revealed by comparing a resistant wild soybean with a susceptible cultivar. The Crop Journal, 3(6), 451-467. https://doi.org/10.1016/j.cj.2015.07.001

Wang, X. W., Li, P., \& Liu, S. S. (2017). Whitefly interactions with plants Current Opinion in Insect Science, 19 , 70-75. https://doi.org/10.1016/j.cois.2017.02.001

War, A. R., Paulraj, M. G., Ahmad, T., Buhroo, A. A., Hussain, B., Ignacimuthu, S., \& Sharma, H. C. (2012). Mechanisms of plant defense against insect herbivores. Plant Signaling \& Behavior, 7(10), 1306-1320. https://doi.org/10.4161/psb.21663 
War, A. R., Paulraj, M. G., War, M. Y., \& Ignacimuthu, S. (2011). Herbivore-and elicitor-induced resistance in groundnut to Asian armyworm, Spodoptera litura (Fab.) (Lepidoptera: Noctuidae). Plant Signaling \& Behavior, 6(11), 1769-1777. https://doi.org/10.4161/psb.6.11.17323

Zhou, S., Lou, Y. R., Tzin, V., \& Jander, G. (2015). Alteration of Plant Primary Metabolism in Response to Insect Herbivory. Plant Physiology, 169(3), 1488-1498. https://doi.org/10.1104/pp.15.01405

Zipfel, C. (2014). Plant pattern-recognition receptors. Trends in Immunology, 35(7), 345-351. https://doi.org/ 10.1016/S1471-4906(01)01972-X

\section{Copyrights}

Copyright for this article is retained by the author(s), with first publication rights granted to the journal.

This is an open-access article distributed under the terms and conditions of the Creative Commons Attribution license (http://creativecommons.org/licenses/by/4.0/). 